\title{
The Sa'ban of Borneo and Zomia
}

\author{
Alasdair Clayre \\ Universiti Malaysia Sarawak \\ alasdairclayre@gmail.com
}

\begin{abstract}
Much has been written about multiculturalism in Borneo, but little research has been done to explain it, let alone its persistence, despite gloomy forecasts of the decline in language and cultural diversity around the world. The Sa'ban of Sarawak and Kalimantan are one of the smallest ethnic groups in Borneo and live in a uniquely multicultural setting. Does Scott's influential depiction of Zomia offer a framework to explain, even predict, the continuance of Sa'ban identity? This paper offers some speculative observations on the parallels between the Sa'ban and Scott's Zomia societies in advance of more extensive fieldwork.
\end{abstract}

Keywords: Cultural diversity, multiculturalism in Borneo, Sa'ban identity, Zomia societies, Long Banga

Copyright: This is an open access article distributed under the terms of the Creative Commons Attribution-NonCommercialShareAlike 4.0 International (CC BY-NC-SA 4.0) license which permits unrestricted use, distribution, and reproduction in any medium, for non-commercial purposes, provided the original work is properly cited.

\section{INTRODUCTION}

This paper introduces the Sa'ban of Sarawak and Kalimantan and explores two central questions: How has Sa'ban identity evolved and persisted, seemingly against the odds, until today? How might Scott's concept of Zomia (2009) help us to understand these processes? In order to answer these two questions, this paper looks at parallels between Sa'ban society and those of Scott's Zomia, in an empirically grounded attempt to develop a theoretical framework to explain how the Sa'ban have formulated and maintained their identity.

My own interest in the Sa'ban specifically stems from spending my early childhood in Long Banga, the principal Sa'ban settlement in Sarawak. My parents came from Britain to Borneo, from 1964 to 1968, as trained Bible translators, joining the Borneo Evangelical Mission (BEM) at the established Bible School in Lawas. From there they were invited to Long Banga by Tama Maria, to produce the first written versions of Sa'ban and translate sections of the Bible in collaboration with church elders, who included Tama Kalang and Tama Maria. I am "adopted" into these families. Both men, and their sons, Tama Ken and Paulus Balan, have contributed greatly to my mother's continued research on the Sa'ban (see various writings of Clayre, B. in References), and Paulus, my "brother", is my principal guide and informant. Throughout my adult life my mother and I have returned to Long Banga and are considered, to some extent, to be members of the community, even, perhaps confusingly, to be Sa'ban, with local names. I am investigating what it means "To be a Sa'ban" for a PhD at UNIMAS, Kuching, Sarawak. Much of my research draws on this collaboration of over 50 years. 


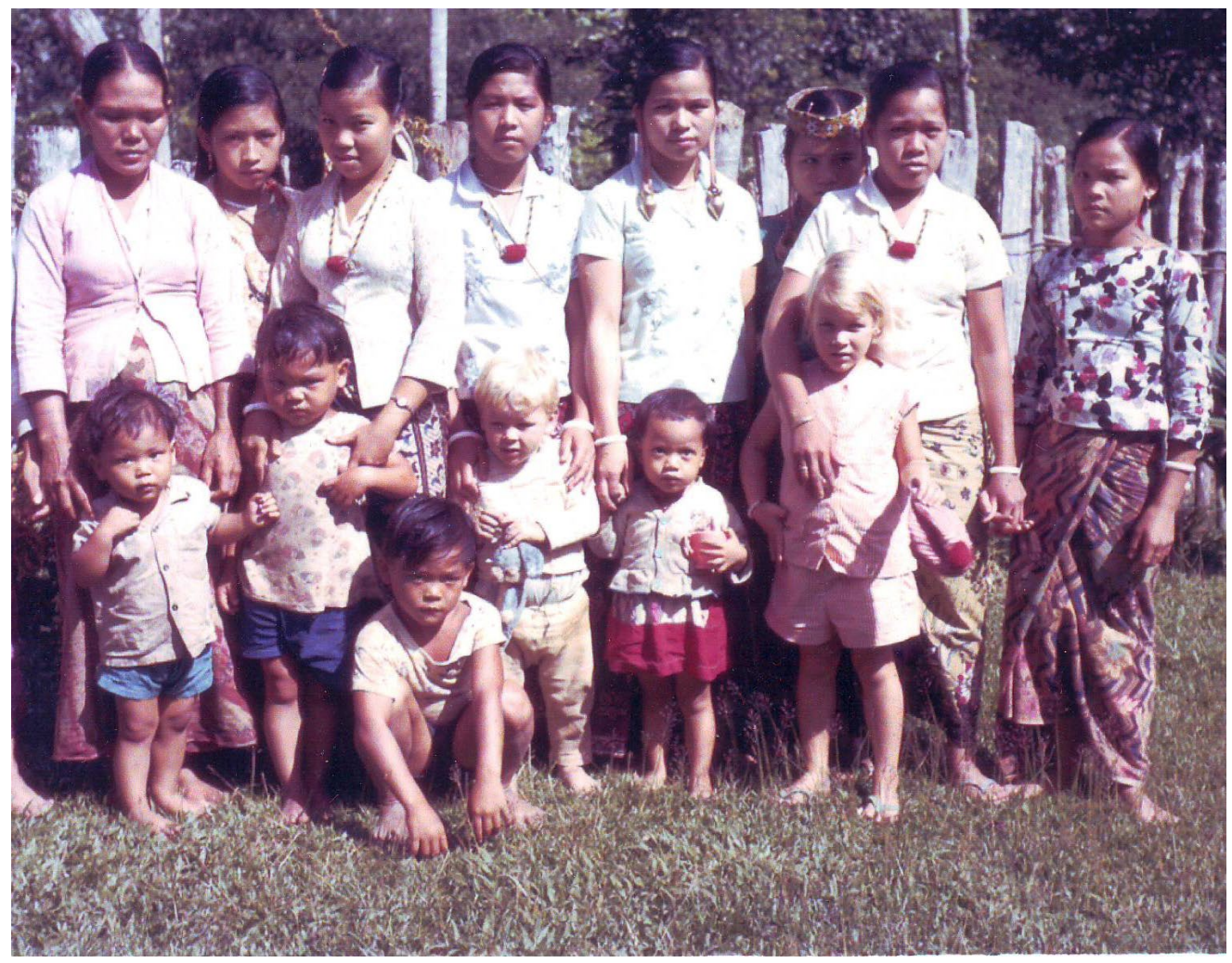

Plate 1: A photo of me in the middle with Paulus Balan on the left, Long Banga, 1968

(C) Beatrice Clayre

The Sa'ban are a small, self-identifying, sociolinguistic, or ethnic group living on both sides of the border in the highlands of Sarawak and Kalimantan. There are no official statistics in either state for their numbers but estimates from the penghulu in Long Banga and other informants suggest there are between 1,000 and 1,500 in each state. The Sa'ban migration from Dutch Borneo, from the Krayan and Bahau regions, to their current settlements around Long Banga in Sarawak began as they, along with other groups, established formal ties with the Brooke government at the Marudi Peace Treaty in 1908. Migration continued throughout the $20^{\text {th }}$ century, not least in response to the Second World War and the transition to British administration, but also, with the formation of Malaysia, to economic growth and job opportunities. There is clear evidence, in the form of burial sites, engraved stones and perupun (stone mounds, in Sa'ban pelpuun) that the area around Long Banga and Long Peluan had previously been settled, but it is unclear by whom and when. The perupun may date back over 2,000 years and the burial sites from the last 500 years. The Sa'ban claim the area as an old settlement while other commentators attribute the later megaliths to the Ngurek (see Gani, 2019).

Much has been written about cultural diversity in Sarawak and Borneo (see Zawawi, 2008) but there has been little research to explain it, let alone its persistence. By contrast, this has been a focus of study, not least amongst Sociolinguists, in other parts of the world like Amazonia (see Stenzel, 2005), prompted in part by discussions of globalisation (see Parkin \& Arnold, 2014). Pessimistic predictions for a drastic decline in linguistic and cultural diversity over the coming century abound, even in mainstream media (see Strolich, 2018). This is clearly the case for the Sa'ban. There are a number of intertwined challenges to the continued existence of Sa'ban as an identity, including language loss, education, and migration to towns, intermarriage, land-rights and national recognition.

A Sa'ban child born in Long Banga today cannot be officially registered as Sa'ban as the identity is not a choice from the official list of ethnic groups. That child will most likely first go to the Primary School in Long Banga, attended by Kenyah Lepo Ke', Kelabit and Penan children, where the use of their own languages is not allowed. The language of instruction is Bahasa Malaysia and the curriculum is set by the nation's Ministry of Education based in Kuala Lumpur. Teachers may come from all over Malaysia. 
It is common for parents to use Bahasa Malaysia with their children at home in an attempt to boost their performance at school. Progressing through the education system, that same child will continue on to Secondary School in Bario (once five days' walk away, now three hours' drive) and subsequently may further their education in Marudi, Miri on the coast, or farther afield, where he or she may settle, get a job and marry. There are very few job or career opportunities in the village.

In the face of cultural and linguistic decline, groups like the Sa'ban are keen to consolidate their identities. This is evident from the formation of the Sa'ban Association in Sarawak, unofficially in 2001 and approved by the Sarawak Register of Societies in 2003. Likewise, in Kalimantan the Sa'ban Association was formed and approved in 1999 and 2014, respectively. One of the associations' most significant contributions was the publication of preliminary Sa'ban dictionaries in 2013 and 2014. The associations also organised festive, celebratory and more political gatherings. I attended one such event in Kalimantan in 2017, with other Sa'ban from Sarawak. The main topic of discussion was how they could best take advantage of a proposed new road towards the coast.

Amster reports much the same of the neighbouring Kelabit, arguing that these formal associations arise in a direct response to the decline in informal relations in the community $(1998$, p. 4; p. 103). They are construed partly in the context of nation building, but also in response to threats to native land ownership (Amster, 1998, p. 146). He quotes a speech by one prominent Kelabit, Henry Lian Aran, likening the Kelabit to a scattered, broken string of beads for which the Rurum Kelabit Sarawak (RKS) can be a new thread. He also suggests that these associations are not merely concerned with conservation of the group's culture, but are selectively reconstructing it (1998, p. 213). He argues, following Ervine (1996) and Anderson (1983), that community identity has to be "imagined." Even though outside the scope of this study, it is a noteworthy project to explore the extent to which the new informal relationships facilitated by social media have begun to undermine the need for formal associations put forward by Amster.

At the same time, the impending disappearance of primary sources of oral history and tradition amongst the Sa'ban has raised genuine concerns. This concern has been an impetus in the community to document and record them. Some of the older members of the community have been recording as much as they can, while they still can.

The creation of the Sa'ban dictionaries, led by Dr Beatrice Clayre, is another example of Sa'ban tradition being preserved. The process fostered an enduring interest in their own history and culture amongst members of the community, especially several younger, more educated Sa'ban. For example, the 2013 edition is dedicated to Kathleen Tisan Kaseng, one of the few Sa'ban with a university degree at the time, who sadly died of cancer in 2005. Kathleen was initially based in Kuala Lumpur, but later in Kota Kinabalu, Sabah, where she became familiar with the work of the Kadazandusun Language Foundation. This experience encouraged and informed her work on the Sa'ban dictionary project.

Significantly too, Dr Beatrice Clayre had spent time with the Sa'ban in Kalimantan where an international, multidisciplinary team, in conjunction with World Wide Fund (WWF) Indonesia, conducted extensive research from 1991 to 1997. This collaborative project resulted in the official announcement of the Kayan Mentarang National Park in 1996. Importantly, the project's management plan deliberately recruited and trained local researchers, some of whom have since become community leaders, and achieved both land-rights and a management role for indigenous groups living within the park. Other prominent international researchers included Christine Eghenter and Bernard Sellato, whom I cite below.

Suffice it to say that these forms of engagement with international scholars are international and global influences on Sa'ban's identity, which need to be considered seriously. The Sa'ban are interested to create an account of themselves not just for themselves and future generations, but to project that identity within the state, the nation and beyond. Like other communities in the Baram, the Sa'ban are well aware of the status the Penan have achieved in international media, the academic interest the Penan have attracted, and the work of the Bruno Manser Foundation: Long Lamai, a principal Penan settlement, 
is only four $\mathrm{km}$ from Long Banga. Some Sa'ban seek to emulate Penan success in projecting their identity to a wider audience.

\section{THE SA’BAN AND ZOMIA}

Scott opens the Preface to his influential book, The Art of Not Being Governed: An Anarchist History of Upland Southeast Asia (2009), with a geographical description of Zomia: "a new name" given by Willem van Schendel (2002) "for virtually all the lands at altitudes above roughly three hundred meters all the way from the Central Highlands of Vietnam to northeast India." Throughout his book, however, Scott describes Zomia more as a social space than a cartographical one. He argues that people have chosen to live in these sparsely populated, hilly margins between states, far from centres of power and have developed societies adapted to maintain their independence. In Scott's work, Zomia becomes a theoretical construct which can also be applied to many other Zomia-like regions in the world, including the highlands of Borneo.

This section begins with a brief overview of the geographical and social settings of the Sa'ban, who previously and elsewhere, like many groups in Zomia, may be referred to, and refer to themselves, by various other names and spellings, including "Saban", "Saben", "Berau" and "Ngaben", or by toponyms. In both geographical and demographic terms, the Sa'ban have historically occupied a zone which exemplifies Scott's notional Zomia. They live in the highlands on the border amid a collection of smaller ethnic groups. In fact, in his elaboration of Zomia, Scott himself draws on accounts of Borneo societies written by scholars such as Tsing (1994), Zawawi (2008) and Sellato (2002, 2016).

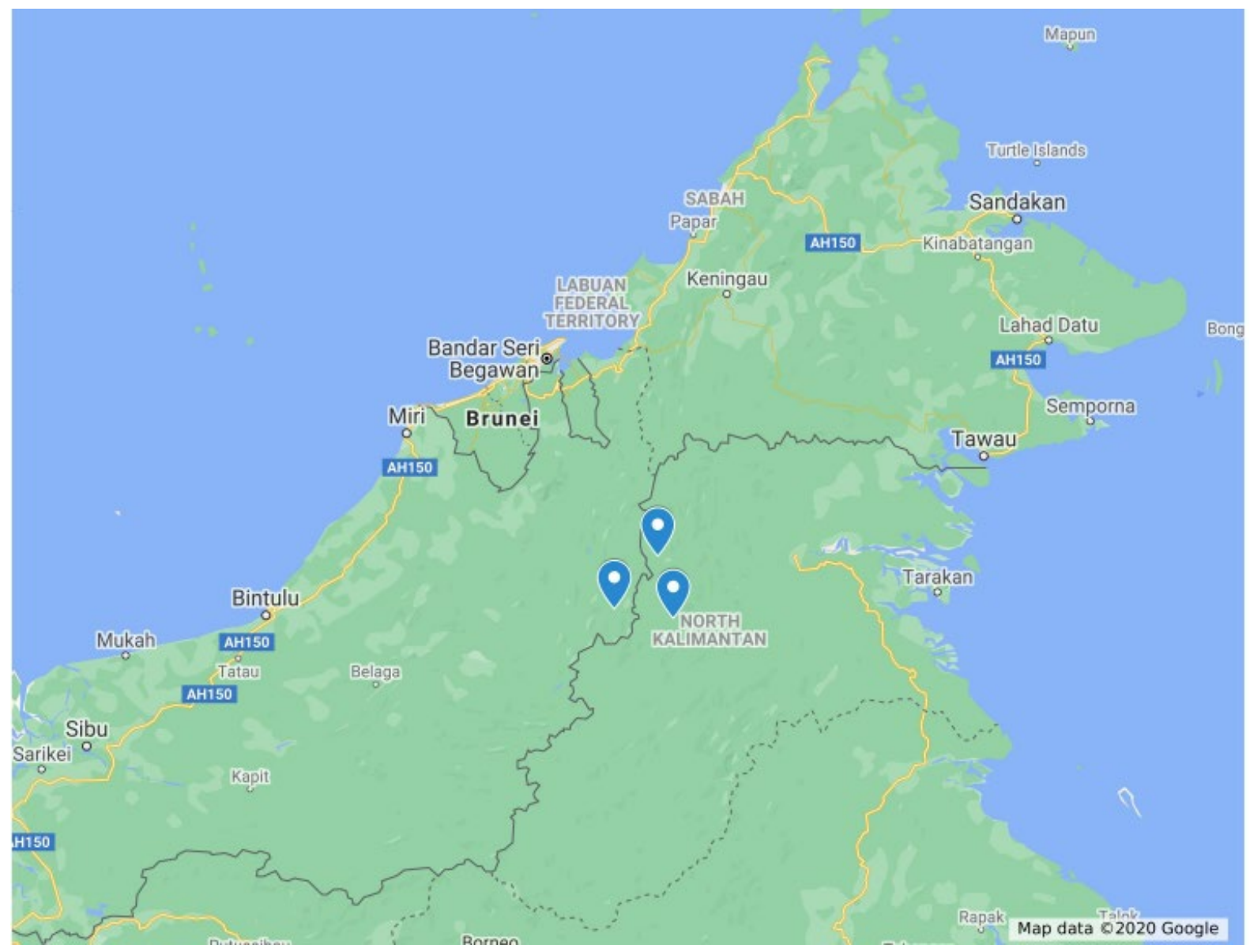

Map 1: Approximate locations of Sa'ban settlements in Sarawak and Kalimantan highlands

The Sa'ban have been grouped with the Kelabit, Lun Bawang and Tring, because of their language similarities, variously referred to as, for example, the Kelabitic-Murut (LeBar, 1972), Apo Duat 
(Hudson, 1978) or Apad Wat (Mashman, 2018). They have often been viewed as a sub-group of the Kelabit. Amster observes that they were, for example, specifically included for the 1986 Kelabit Carnival (1998, p. 152). Central to Mashman's (2018) thesis is that the Kelabit and Sa'ban are included in the term lun tauh, our people. It has certainly been expedient for Sa'ban to describe themselves as Kelabit, for bureaucratic or practical purposes, whether on forms or to people who would not have heard of the Sa'ban. Undoubtedly, the Kelabit and the Sa'ban are close, linguistically and culturally. They are neighbours, and the Sa'ban have historically come under Kelabit jurisdiction and penghulus. This explains my frequent reference to publications about the Kelabit, about whom much has been written, compared to the scant literature on the Sa'ban. Ose Murang, a Kelabit from Long Peluan, wrote a short piece, "The Sa'bans of Sarawak" in the Sarawak Museum Journal (1989; see also, 1993). Kelvin Egay, who is also part Kelabit, took up the challenge in his paper, "Re-situating the Sa'ban Ethnography: A Reflection on the Notion of Representation", stating, "Academic research on the Sa'ban community in Sarawak is lacking" $(2009$, p. 136).

But, curiously, whereas the Sa'ban and Kelabit live in neighbouring villages, the Sa'ban share Long Banga village with the Kenyah Lepo Ke', a linguistically and culturally distinct people with whom they have often been grouped too, as in the first mentions of the "Sabang" (sic) in print, by Douglas in the Sarawak Gazette reporting on preludes to the Marudi Peace Treaty of 1908 (Douglas, 1908a). This living arrangement, which has endured from Kalimantan to Sarawak, may be unique in Borneo and make the Sa'ban of particular interest for the study of enduring identity.

In Sarawak, the Sa'ban principally live in the village of Long Banga, with the Kenyah Lepo Ke'; in the nearby smaller village of Long Puak (aka Long Balong); and in Miri, a town on the coast. Some Sa'ban also live in Long Peluan, a neighbouring, nominally Kelabit village, and Marudi, a small trading town up the Baram river, near the coast. Fewer still live in Kuching, Kuala Lumpur and beyond, but a significant number of Sa'ban men have worked around the globe, offshore, in the oil industry.

The highlands of Sarawak and Kalimantan, and their people, are divided by a mountain range which runs roughly south-south-west to north-north-east. This mountain range is the watershed for the major rivers along which many of the peoples of Borneo live. Locally, the mountain range which divides the Kelabit and Sa'ban from their neighbours across the border is known as the Apad Wat, hence the name given to this ethnolinguistic group.

Long Banga and Long Puak are located above the navigable stretches of the Baram river, $200 \mathrm{~km}$ inland from the coast, $20 \mathrm{~km}$ east of Lio Mato (a Kenyah Badeng community), the highest point reachable by boat from the coast, and $60 \mathrm{~km}$ south of Bario in the Kelabit Highlands. These distances belie the relative isolation of Long Banga. When I first returned there as an adult in 1988, I flew one hour from Miri to Bario in a small plane, walked five days south to Long Banga, then walked two days west to Lio Mato and took a fast longboat two days downriver to Marudi. Today Long Banga has its own airstrip, with two scheduled flights per week. It can be reached by logging road from the coast in approximately eight hours. Bario is a further three hours' drive, road conditions permitting.

There are also three Penan villages in the vicinity. Long Lamai, the oldest Penan settlement in Sarawak, first established in 1958, lies four km (or two hours' walk) south of Long Banga. Long Beruang is near to Long Peluan, and Ba Lai some 16 km northwest, across the Baram. The Penan were Sarawak's nomadic hunter-gatherers who have settled, for various reasons, over the last sixty years.

The area is known as the "Punang Kelapang". It stands out for its relative isolation and for the four groups, Penan, Sa'ban, Kenyah and Kelabit, living side by side. The name refers, in Kelabit, to the headwaters of the Baram, and includes Pa Dalih, the next Kelabit village two hours' drive north towards Bario. The people of these villages have deep historical ties, explored by Mashman (2018).

In Kalimantan the Sa'ban live principally in villages in the Bahau and Krayan, in the towns of Malinau, towards the coast, and Tarakan, on the coast. In these settings they also co-exist alongside other peoples. 
The Indonesian authorities gathered different sociolinguistic groups together in settlements like Long Layu and Tang La'an following the Confrontation.

\section{ZOMIA, ETHNOGRAPHY AND HISTORY}

In her review of Scott's book, Mandy Sadan of the School of Oriental and African Studies (SOAS) is somewhat scathing of the broad "sweep and scale of the thesis" in which "Time depth becomes a concertina performance... with supporting examples for Scott's fundamental ideas seeming sometimes to be cherry picked from around the globe and across time and space." (Sadan, 2010, p. 6) I look at parallels between Sa'ban society and those of Scott's Zomia, in an empirically grounded attempt to develop a theoretical framework to explain how the Sa'ban have formulated and maintained their identity.

A second important limitation of Scott's model, in Sadan's words, is that "we are told that the only historical period we should discount from the model he proposes is the period after the Second World War because of the intensification of the process of state enclosure. But why...?" (Sadan, 2010, p. 3). This is an important question especially since much of what we do know of the Sa'ban post-dates the Second World War. With that, it will be worthwhile to explore, using Scott's hypothesis, the adaptations of societies like the Sa'ban pertaining to their patterns of livelihood and migration, interaction with more powerful groups, social organisation and kinship in the post-war period.

Thirdly, despite the reported decline in linguistic and cultural diversity around the world, let us not forget, echoing Scott's wry observation (2009, p. 9), that the Sa'ban's identity has survived, even been more stable, than the three successive regimes in Sarawak, under the Brookes, under the British and within Malaysia (2009, p. 9). This raises questions: how has this been possible? What lessons for the future can we draw from the persistence of Sa'ban identity?

There is some ambivalence amongst anthropologists about historical approaches. In his preface, Scott (2009) is almost self-disparaging about becoming a historian. My own ambivalence stems from wondering how do the Sa'ban see themselves and the extent to which individual Sa'bans give importance to historical narratives. This might be a question for people any where. To what extent does a British or a Malaysian person refer to their history (let alone reliably) in summing up what it is to be British or Malaysian. When challenged over what it meant to be British during the run-up to the Brexit referendum, Prime Minister David Cameron listed a series of values, invoking some ridicule. Likewise, when I asked an educated Kelabit in Bario what it meant to be Kelabit, he listed the values, notably sakai (hospitality, caring) as paramount, without reference to geography or history. Amster shares a similar experience in Bario: "However, it turned out that local history was of much less interest to most Kelabits than I could have anticipated" (1998, p. 6).

Looking to the highlands, a traditional, deterministic view was that these groups were undeveloped, remnant "primitives" occupying isolated, even specific, ecological niches (see Scott's Preface). Early commentators like Hose were often amateur zoologists with Darwinian perspectives and had notions of social evolution. When Van Walchren first mentions the people we will come to know as Sa'ban, he describes them, in 1906, as "not on a high level of civilization" (1907, p. 822). Douglas, the Resident in Marudi in 1912, describes the tribes beyond Lio Mato as "the wildest" (1912, p. 20). Jongejans sets out to meet "the primitive Sabans" in Dutch Borneo in 1917 (1922, p. 215). In 1940 the Sarawak Gazette still referred to those living in the headwaters of the Baram river as "a people who are one of the least civilized in Sarawak" (1940, p. 48). Later observers might justifiably have seen these groups, the Sa'ban or the Ngurek (see Sellato, 2016), as the remnants of formerly expansive groups, reduced by famine, epidemics and war. There has been little attempt to explain the persistence of identities like the Sa'ban, Tring or Ngurek. The latter two survive in pockets with the Berawan and Kenyah.

Other commentators have suggested a process of "devolution". In his $1983 \mathrm{PhD}$ Thesis, Hoffman suggested that the Punan had essentially devolved to nomadic hunting-gathering from a sedentary, agricultural lifestyle. While this view has been controversial, Paulus Balan reports that one group of 
Sa'ban, along the Tawan river in Kalimantan, were nomadic. Scott himself refers to Punan and even Kenyah and Sebop farmers returning to nomadic hunting-gathering for periods, not least in times of war $(2009$, p. 198). It should be emphasised that the difference between truly nomadic hunter-gatherers and swidden agriculturalists was considerably less until recent times. Swidden farmers still depended a great deal on produce hunted and gathered from the forest and rivers.

In 2009 Scott offers a compromise: "Upland communities, far from being the original, primal 'stuff' from which states and 'civilizations' were crafted, are, rather, largely a reflexive product of statemaking designed to be as unappealing as possible as a site of appropriation" $(2009$, p. 327). Near the beginning of his book, Scott describes Zomia as "a zone of refuge or 'shatter zone,' where the human shards of state formation and rivalry accumulated willy nilly, creating regions of bewildering ethnic and linguistic complexity" (2009, p. 7), These "human shards" may well have arrived in the uplands as a result of shattering, but, more importantly, Scott progresses to refer throughout his book to the "shatter zone" as a place where shattering continues. Or more precisely, far from it being evidence of a linear demise, "dissolving, splitting, relocating, merging and reconstituting" $(2009$, p. 36) was a strategy, a cultural adaptation, which enabled highland groups to continue to evade famine and disease, dominance and slavery, to survive. From this point of view, not only do these supposedly isolated groups have relationships with their powerful neighbours but have formed in response to those relationships. Neither coastal populations nor highland people, nor intrusive larger groups like the Kayan, exist independently of each other. They define themselves in a "pattern of paired symbiosis and opposition" (2009, p. 29). Just as the highland tribes may disparage the lowlanders, and vice versa, as tame or wild, developed or primitive, they have commonalities, and rely on each other for trade. They develop blood-brotherhoods. There are often even kinship links. The Kelabit claim a distant kinship with the Brunei Sultanate, for example (Mashman, 2018, p. 186).

Scott suggests that villages we now think of as Kelabit or Sa'ban were able to disassemble and reassemble much like a pile of bricks (2009, p. 210). Scott's approach has many merits. Not only does it help to explain the persistence, albeit mutably, of identity over time, but it portrays the articulators of those identities not as passive victims of history but as actors making it. This agency is an important emphasis of ethnography in recent years. Far from being the unwilling objects of government, Mashman (2018) describes how the people of Long Peluan made a "quest for the "life of government", and Clayre (1997) "How the Sa'ban went to Marudi to make peace".

The fragmenting pressures on these groups in the highlands are familiar from historical records, scholarly accounts and Sa'ban narratives. They include famine, disease, difficulties with powers nearer the coast and invasion by larger groups. Their responses to these pressures, argues Scott, are to have highly mobile, smaller organisational groups with appropriately flexible agriculture, social organisation and kinship.

Certainly, in living memory, Sa'ban society was scattered. Before the Sa'ban in Kalimantan were gathered together, with other groups, into larger villages following the Confrontation, they lived in small communities dotted throughout the Bahau and Krayan. It is from those villages they migrated to Sarawak, bringing with them slight variations in vocabulary and pronunciation and, it has been suggested to me, leadership struggles. The Sa'ban have no oral record of where they may have come from before that, although claims that the Long Banga area was an ancient Sa'ban settlement may suggest they once criss-crossed the mountains that now form the border. Given the similarities of the Sa'ban and Lun Bawang languages, and that Sa'ban is found the furthest south of any of the Apad Wat languages, it is tempting to speculate that they previously migrated from the north.

The Sa'ban do claim to have been a larger, more established group historically, centred in what are now the grasslands of the Bahau region. Tama Maria took Paulus Balan and his other sons to show them their ancestral territory and its megaliths. This is a four day walk east from Long Banga over the mountains on an ancient route marked with a carved stone, Batu Kalong, on the ridge. Sa'ban adat, or tradition, prohibits marriage with anyone closer than a fifth cousin which suggests a large population to choose from, but we cannot presume that this population necessarily represented an established 
community identifying as Sa'ban or whether, as seems more likely, there were extensive kinship links between different communities. It is therefore hard to say whether the Sa'ban were "shards" of a previously bigger society, but we can explore their grouping patterns in more recent times.

\section{INTERACTION WITH INVADING FORCES}

In the middle of the $18^{\text {th }}$ century "demographically and militarily powerful" Kayanic groups arrived in force in the Bahau region where they over-ran, enslaved and scattered communities (Sellato, 2016, p. 120). The Ngurek took shelter with other tribes, including the Sa'ban, or moved further away. The Sa'ban still talk about this relationship with the Ngurek, and the Kelabit recently held a homecoming irau (a celebratory gathering) in Long Peluan for long-lost Ngurek kin.

It is imperative to note, as Scott reiterates throughout his book that the greatest resource being fought over historically was not territory, but people (see e.g., 2009, p. 67). In the sparsely populated marginal areas of Zomia or Borneo, land was not scarce, but people to work it were $(2009$, p. 83-84; p. 149). The response of threatened peoples was therefore not so much to defend their territory, but their independence. Swidden agriculture meant they could relatively easily abandon their farms and clear new ones elsewhere. In the meantime, they also knew how to survive on jungle produce, including sago, and typically their dwellings were relatively temporary structures compared to later longhouses.

The highlands of Borneo may be famous in the popular imagination for headhunting, but raids for slaves were also a constant threat. Of course, slavery takes on many forms, but slave-taking and trading were prevalent throughout South East Asia and the extent of it needs to be appreciated. Scott notes that "Fear of Malay slave raiders in the early colonial period had depopulated many of the coastal areas of Burma and Siam" (2009, p. 150), and that "fully three-quarters of the kingdom of Chiang Mai's population in the late nineteenth century consisted of war captives" $(2009$, p. 86). The northern tip of Borneo, near Kudat, is known by the local Dusun as Tanjung Sampang Mangazou, a name which celebrates the defeat of slave-traders.

The ability to scatter, or "shatter", to keep their heads, avoid becoming slaves or being subsumed into Kayan society not only allowed the Sa'ban and other communities to maintain their independence and identities, but according to Scott is a defining aspect of their societies and identities. As such it shapes their social organisation and kinship structures.

\section{SOCIAL ORGANISATION AND LEADERSHIP}

This is a complex topic to cover here in any depth, but the Sa'ban, like their Kelabit neighbours, had a stratified society, with aristocrats, paran, commoners, lun we', and slaves, lemluen. Slaves in turn were divided into original slaves, lemluen taeu, descended from the slave class established in a founding myth, and lemluen raang ma', war captives who were often children. According to Paulus Balan, the slaves captured in raids might be better treated than those born into captivity because they may have come from higher ranks in their own societies. A Kelabit informant suggests that slaves were treated quite well, as members of the household, a view shared by Tama Maria who remembers his family having slaves when he was a young boy. Nonetheless, slaves might be buried with their owners to accompany them into the afterlife, and Tama Maria tells how one particularly beautiful slave in their household, Sueng Aran, despite having many suitors, refused to marry. She said she did not want her children to live a life like hers. Marrying down was a one-way ticket that would impact the status of descendants and their marriage prospects indefinitely.

In the founding myth of the class system there were only aristocrats and slaves, but paran must demonstrate the right qualities of character to maintain their status. These qualities include being strong and brave, wise and active in decision-making for the community, hardworking enough to accumulate the wealth to throw appropriate feasts and abstaining from marrying a slave! Paran who did not demonstrate these qualities became commoners. Their descendants might become paran again through marriage and by displaying such qualities. 
Some informants have suggested to me that the Sa'ban may have borrowed features of their hierarchy from the Kayan. Scott argues that Zomian groups commonly adapt their social structure to interact with neighbouring powers $(2009$, p. 207). Thambiah (2020) has recently suggested that Kayan dominance, at least in part, explains Bhuket notions of stratification, despite a generally egalitarian ethos. To explain what she means by the latter she takes "two points from Sahlin's [1958] definition of egalitarianism that (1) the qualification for higher status may lie in personal characteristics, and (2) that every individual has an equal chance to succeed to whatever statuses may be open" (2020, p. 158). With reference to similar observations by Sellato, she essentially argues that "among the Bhuket, ranking and egalitarianism co-exist" (2020, p. 169). Put simply, if social mobility is a defining feature of egalitarian societies, those societies must have strata to move between. It would be wrong of me to equate Sa'ban or Kelabit hierarchies directly with those that Thambiah describes. Sa'ban and Kelabit sources insist that their societies were (and are) distinctly hierarchical; but those same sources would also concede that they were not as strictly stratified as Kayan society. It is tempting to observe a paradox. Bala makes the case that social mobility was possible amongst the Kelabit in her analysis of do-ness, good-ness (2008). Janowski asks "Who's in charge around here?" (2013), implying, as is my experience with the Sa'ban, that it is not always clear. One notable Sa'ban headman in Sarawak was known to be descended from a slave (albeit he was a runaway masquerading as a relative) which challenges the notion that membership of the slave class excludes descendants from becoming paran indefinitely.

Thambiah and Sellato argue that personal attributes and charisma were traits which could enable men to become leaders, much as Paulus Balan describes the qualities required of the paran. Whether this represents a "plasticity of social structure" (Scott, 2009, p. 218) amongst the Sa'ban, I will have to explore further. Certainly, new communities were formed by challenges to leadership and fission in the past. Jostling for leadership roles, even attempts a fission-like schisms, continue to this day in Sa'ban communities.

Christianity, education, money, and government involvement in the appointment of leaders, have changed the landscape of social organisation and leadership, offering different routes up the social ladder, yet arguably the picture remains remarkably unchanged. Those who were most likely to advance through the church and education tended to come from historically privileged families. Class remains a predeterminate in the choice of headmen and who should marry. I have had several discussions recently about the apparent resurgence of class-consciousness and affiliation among Kelabit and Sa'ban, which merits further investigation.

Given the above discussion of flexible leadership and class-structure, we can understand how Sa'ban communities under threat could readily splinter into autonomous units for their continued survival. This brings me to kinship and household structure.

\section{KINSHIP}

Early anthropologists were somewhat stumped by Sarawak kinship which challenged their received models (King, 2017, p. 19). Kinship amongst the Kelabit and Sa'ban is bilateral and cognatic. Adoption has been commonplace. Blood brotherhoods exist within and between separate groups, and kinship terms are applied beyond genetic relatives. Many commentators have found that the "hearth-group" is a more useful unit to consider (see Janowski, 2007; Armstrong, 1991) in constituting longhouse societies. This is a relatively autonomous unit which farms, eats and lives together. Hearth-groups may combine their efforts reciprocally, but even the headman would be responsible for farming his own land. Such units can readily disperse and reassemble to form new hamlets or villages, in accordance with Scott's model, but this loose form of kinship also enhances the ability of people to create very wide networks over long distances which would be of supreme importance in times of war and utterly necessary for trade to the coast.

Adoption in the developed western world is largely restricted to the rearing of children. Whilst the adoption of children in the highlands is common, so too is the adoption of adults, typically accompanied 
by the giving of a new name. There may be genuine emotional ties between the parties, as in my case, but motives are often also strategic, linked to material and status advantages, which may be reciprocal. A teacher from West Malaysia in the primary school in Long Banga might develop a relationship with a particular family in the village, often eat in their house, go hunting with them and enjoy the benefits of a home, of kin. Adopted into that family, it might equally prove useful to the locals to have a contact in West Malaysia, with an understanding of how things work in town and a bank account. The same would have been true in the past, when Sa'ban made the arduous journey down-river to Lio Mato and Marudi. Marriages to Chinese traders have not been uncommon either, for similar reasons, and the Chinese families might benefit from access to rural land and produce (see Mashman, 2020, p. 31).

\section{INTERACTION WITH STATE-LIKE GROUPS}

As mentioned above and emphasised by Scott (2009, p. 191), swidden agriculture was more efficient than wet rice farming where land was plentiful and labour scarce. This leaves more time for the gathering of the jungle produce so valuable for coastal trade. In return the lowlanders traded the gongs and Chinese jars which would become the most valuable possessions in the highlands. But the coast was far away and there might be frictions with the powers there, or with other groups between the highlands and the coast. This was certainly the case for the Sa'ban and their neighbours in the Borneo highlands. Difficulties with the Sultans on the east coast of Borneo, in Kalimantan, and with reaching the coast, almost certainly prompted the Sa'ban, Kenyah and Kelabit to establish a better trade route to the west, with the peace treaty in Marudi, Sarawak in 1908, and the establishment of a fort cum trade post in Lio Mato at the head of the Baram river (Douglas, 1908b). The tribes had positioned themselves well on the margins of both regimes and played both sides, a feature of Zomia societies (Scott, 2009, p. 6). The Dutch response to the treaty with the Brooke regime was to limit the authority of the Sultans of Kutai and Bulungan over the highlands (Lumenta, 2011, p. 127) and to establish a military outpost in Long Nawang in 1911 (Sellato, 2002, p. 26). It was during this time some Sa'ban and Kelabit migrated over the border and initiated the settlements of Long Peluan and later Long Banga in Sarawak, although their allegiances would be influenced by the stronger Dutch presence in Kalimantan.

The establishment and development of Long Peluan is chronicled by Mashman in her excellent 2018 $\mathrm{PhD}$ Thesis. Mashman also provides "A Social History of the Fort at Lio Mato" in her as yet unpublished 2020 paper. In both, Mashman emphasises the active role played by local people in their own history, making peace, migrating, wanting and building the fort; but she also notes, as I had, a "muting" (2020, p. 3) of more coercive influences. Douglas, in his Sarawak Gazette entries about the peace-making and the fort, paints an equally pacific and happy picture, omitting a crucial part of the story: his punitive expedition across the border in 1905. Even his reports in 1905 gloss over what he describes some years later, in 1912 in the Sarawak Museum Journal, as a "Government Expedition" which "... in seven roaring days in the enemies country destroyed 30 villages and killed some 200 of the offenders" (Douglas, 1912, p. 18, cited in Mashman 2020, p. 13). Mashman goes on to discuss how the excessive violence of one of the raid's leaders, Penghulu Aban Tingang, was inferred and downplayed.

As yet I have found no evidence from the Sa'ban that they suffered directly from the 1905 expedition and felt coerced into the 1908 peace treaty or subsequent migration, but it is a hard factor to ignore. By contrast, in advance of their major migrations to Sarawak at the end of the Second World War, the Sa'ban were clearly intimidated by Major Tom Harrisson, the leader of allied forces in the interior. In Paulus Balan's words, from my notes:

"Whatever Tuan Mayor [Tom Harrisson] or any White Tuan said was a directive that cannot be refused. They have seen with their own eyes how Tuan Mayor punished those who disobeyed his command. At one time, Tuan Mayor shot their pigs in front of them for being late to welcome his visit... They also knew that even the most respected and brave Penghulu Mere' bowed down to Tuan Mayor. Thus, when Tuan Mayor asked them to migrate to the Baram, there was no way to refuse. Many of them were reluctant to migrate and tried to find excuses such as telling him that the omen was not good, but he told them to make their journey whenever the omen was good." 
According to the Sa'ban, Tom Harrisson urged them over to Sarawak where he could "look after them" (Paulus Balan's words) because they hid Donald Hudden, the Marudi District Officer, from the Japanese (see Clayre, 1999), but there was some confusion about what he meant. Clearly, some stayed behind and some migrated, sending the Sa'ban on different economic and political trajectories. I do not have the space to outline here the similarities and differences of those trajectories, of how the Sa'ban on either side of the border adopted Christianity, experienced the Confrontation or the formations of independent Indonesia and Malaysia, but what is striking is their ambivalence towards state authority and the extent to which the Sa'ban continued to forge a common identity despite the split. To maintain the analogy with Scott's Zomia, this split is in many ways merely a continuance of their earlier disparate existences.

\section{CONCLUDING OBSERVATIONS}

To conclude, let us return to my opening, central questions. How has Sa'ban identity evolved and persisted, seemingly against the odds, until today? Sa'ban identity has not persisted unchanged. Rather, the Sa'ban have successfully adapted to change and sought both to consolidate and articulate their own identities over time and space. Their ability to do so is enhanced by a historically honed flexibility of social organisation and kinship, and identity.

Similar observations about identity are made in other contributions to Borneo ethnography in recent decades. For example, Liana Chua's 2007 paper, "'Fixity and Flux: Bidayuh (Dis)engagements with the Malaysian Ethnic System", describes the fluid relationship Bidayuhs have with their exonym, how this has evolved from colonial to nation-state times, and how individuals may articulate seemingly paradoxical or contradictory identities under different circumstances.

In discussion with a prominent professor of linguistics in Oxford, he drew for me a simple analogy: we often read of language-trees, of proto-languages, but that is to ignore that a tree has roots spreading out in all directions too. People come together and disperse, repeatedly, in time and space. As they do, so their languages, cultures and identities mutate, and not in a linear fashion. In different circumstances they may choose to articulate different aspects from a repertoire of identities. The Sa'ban may at once see themselves as lun tauh, or lun tam in Sa'ban, as the same people as the Kelabit, and distance themselves from the Kelabit. One Sa'ban described to me how the Sa'ban sometimes feel like the poor cousins of the Kelabit in Sarawak, but that in Kalimantan they were the Kelabit, meaning the more powerful, educated, successful and dominant group. Scott's (2009, p. 10) "pile of bricks" may not just be used to constitute new villages, but identities.

How might Scott's concept of Zomia help us to understand these processes? Scott reaches a similar conclusion about identity in Zomia: "There is surely something defective about any analytical understanding of identity change that is so radically at variance with the experience of real actors. Ethnic change can, I believe, be differentially formulated so as to accommodate better the vernacular understandings of local actors. If we assume, for many hill people, a plurality of identity repertoires, then it follows, as we have seen, that various portions of that repertoire will be elicited by a particular context of action. Performed identity will, in other words, be situationally cued" (2009, p. 255).

Scott's depiction of Zomia provides an analytical framework to explore the agentive mechanisms by which the Sa'ban have managed to imagine and preserve a sense of identity despite, and even because of, their unusual setting. He shows that, just as the societies we describe are mutable, so too our theoretical perspectives must be flexible:

"There is a paradox in trying to describe a shatter zone or region of refuge such as Zomia. In order to portray the flux and plasticity of hill societies one has, necessarily, to stand somewhere, even if that "somewhere" is itself in motion" (2009, p. 331). 
His sentiment is echoed by Chua: "you can see a real emphasis on 'transformation' as the defining condition of Borneo studies..." (Chua, 2018, p. 5). By this she includes not just transformation in the societies we describe, but "...transforming our own scholarly models and practices" (Chua, 2018, p. 3). Or, as Tsing observes in The Realm of the Diamond Queen (1993), "Instead, the guerrilla tactics of multiple, uneasily jostling theories and stories can at least disrupt the smug assumptions of comfortably settled monologics" (Tsing, 1993, pp. 32-33). Likewise, while she may be sceptical of Scott's approach to history, Sadan concludes that Scott gives us "a paradigm for 'thinking' about the uplands" which "can be an incredibly liberating and useful model to provoke new understandings and directions" (Sadan, 2010, p. 6).

Responding to Sadan's earlier criticisms of Scott, I have looked, through the lens of Zomia, at one group in one part of the word, chronologically, and beyond the Second World War. I have shown, following Scott, how Sa'ban identity is closely linked to their historical position in the highlands. I have argued that the migration of the Sa'ban into Sarawak is in keeping with Scott's paradigm. I will have to explore more recent parallels in a future paper, but might not the lens of Zomia offer insights into more recent migrations to town and in search of jobs? Can we make meaningful comparisons between a swidden lifestyle and contemporary work and residency patterns, or at least with the transition from one to the other? Scott provides a helpful framework to explain multicultural co-existence in highland regions in the past. We will have to see whether the very adaptability Scott ascribes to Zomia groups may not be what sustains $\mathrm{Sa}$ 'ban identity into the future. 


\section{REFERENCES}

Amster, M.H. (1998). Community, ethnicity and modes of association among the Kelabit of Sarawak, East Malaysia [PhD Dissertation, Brandeis University].

Anderson, B.R.O'G. (1983). Imagined communities: Reflections on the origin and spread of nationalism. Verso.

Armstrong, R. (1991). People of the same heart: The social world of the Kenyah Badeng. [PhD Thesis, University of Sydney].

Bala, P. (2008). The desire for progress: The Kelabit experience with Information Communication Technologies (ICTs) for rural development in Sarawak, East Malaysia. [PhD Dissertation, University of Cambridge].

Chua, L. (2018, August 6-8). Borneo Studies as a "more-than-" project: Openings and connections [Keynote address]. Borneo Research Council Conference, Kuching, Malaysia.

Chua, L. (2007). Fixity and Flux: Bidayuh (Dis)engagements with the Malaysian Ethnic System. Ethnos, 72(2), 262-288.

Clayre, B. et al. (2014). Kamus Sa'ban Hmeu Sa'ban. Persatuan Masyarakat Saban Miri. Sarawak. Malaysia.

Clayre, B. et al. (2013). Kamus Sa'ban Si' Latoon. Persatuan Masyarakat Saban Miri. Sarawak. Malaysia.

Clayre, B. (2010). Secondary Burial among the Sa'ban of Sarawak. In T. Armsbruester and M. Hegewisch (Eds.), On pre and earlier history of the Iberia and Central Europe: Studies in honour of Philine Klab (pp. 280-288). Verlag Dr Rudolf Habelt GmbH.

Clayre, B. (1999). The fate of Donald Hudden. (Brief Communications). Borneo Research Bulletin, $140+$.

Clayre, B. and Usat, B. (1997). How the Sa'ban went to Marudi to make peace. Sarawak Museum Journal, LI(72), 15-19.

Clayre, B. (1994). Sa'ban: A case of language change. In P.W. Martin (Ed.) Shifting patterns of language use in Borneo (pp. 209-226). Borneo Research Council.

Clayre, B. (1972). A preliminary study of the Lun Bawang (Murut) and Sa'ban languages of Sarawak. Sarawak Museum Journal, XX(40-41), 145-171.

Douglas, R.S. (1912). An expedition to the Bah country of Central Borneo. Sarawak Museum Journal, l(2), 17-29.

Douglas, R. (1908a, April 8). Sarawak Gazette, 90.

Douglas, R. (1908b, June 16). Proposed Fort at Lio Matu. Sarawak Gazette, 156. 
Egay, K. (2009). Re-situating the Sa'ban ethnography: A reflection on the notion of representation. Akademika, 77, 133-148.

Eghenter, C. and Sellato, B. (2003). Introduction. In C. Eghenter, B. Sellato, and G.S. Devung (Eds), Social science research and conservation management in the interior of Borneo: Unravelling past and present interactions of people and forests. Center for International Forestry Research. Indonesia.

Gani, N. (2019). Megalithic sites in Punang Kelapang, Upper Baram, Sarawak: a preliminary survey. Jurnal Arkeologi Malaysia, 32(2), 13-30.

Gilmartin, M., Wood, P. and O'Callaghan, C. (2018). Borders, mobility and belonging. Bristol University Press.

Hoffman, C.L. (1983). Punan [PhD Thesis, University of Pennsylvania].

Hudson, A. (1978). Linguistic relations among Borneo peoples with special reference to Sarawak: An interim report. In M. Zamora (Ed.), Sarawak: Linguistics and development problems studies in Third World Societies No 3. (pp. 1-44). Boswell Printing and Publisher.

Irvine, J.T. (1996). Language and community: Introduction. Journal of Linguistic Anthropology, 6, 123 125. doi: $\underline{10.1525 / \mathrm{jlin} \cdot 1996.6 .2 .123}$

Janowski, M. (2007). Being 'Big', Being 'Good': Feeding, kinship, potency and status among the Kelabit of Sarawak. In M. Janowski and F. Kerlogue (Eds.), Kinship and food in Southeast Asia. (pp. 93-120). NIAS Press.

Janowski, M. (2003). Who's in charge around here? Struggle for leadership in a changing world among the Kelabit of Sarawak. In S. Sparkes and S. Howell (Eds.), The house in Southeast Asia: A changing social and economic domain (pp. 95-113). RoutledgeCurzon.

Jongejans, J. (1922). Uit Dajakland Kijkes innhet leven van den koppenschneller en zijne omgeving. Meulenhoff.

King, V.T. (2017). Identities in Borneo: Constructions and transformations. In V.T. King, Z. Ibrahim and N.H. Hassan (Eds.), Borneo Studies in history, society and culture (pp. 177-207). Springer.

Lawai, L. (2003). A history of the Kenyah Leppo' Tau in Kayan Hulu Subdistrict, Apau Kayan. Social science research and conservation management in the interior Borneo: unravelling past and present interactions of people and forests. 175-198

F.M. LeBar (Ed.) (1972). Ethnic groups in insular Southeast Asia. Human Relations Area Files.

Lumenta, D. (2011). Moving in a hierarchized landscape changing border regimes in Central Kalimantan. Wacana, Journal of the Humanities of Indonesia, 13(1), 121. https://doi.org/10.17510/wjhi.v13i1.12

Mashman, V. A. (2018). A History of Lun Tauh Our People at the Borders of the Kelabit Highlands: from Warfare to the Life of Government and to the Life of Christianity. [PhD Thesis, Universiti Malaysia Sarawak] 
Mashman, V.A. (2020). A social history of the fort at Lio Mato. Unpublished.

Murang, O. (1993). Kelabits, Sa'bans, Kenyah and their Penan neighbours: Partners in development. In V.H. Sutlive Jr. (Ed.), Change and development in Borneo (pp. 83-100). Borneo Research Council Inc.

Murang, O. (1989). The Sa'bans of Sarawak. Sarawak Museum Journal, XL(61), 185-198.

Parkin, D. \& Arnaut, K. (2014). Super-diversity \& sociolinguistics: A digest. Tilburg Papers in Culture Studies, 95.

Sahlins, M.D. (1958). Social stratification in Polynesia. Monograph No. 29. American Ethnology Society.

Sadan, M. (2010, April 30). Review of the book The Art of Not Being Governed: An Anarchist History of Upland Southeast Asia by J.C. Scott. Reviews in History, 903. New Haven: Yale University Press. https://reviews.history.ac.uk/review/90

Sarawak Gazette (1940, February). Fourth Division News. 48.

Scott, J.C. (2009). The Art of Not Being Governed: An Anarchist History of Upland Southeast Asia. Yale University Press.

Schendel, W. van. (2002). Geographies of knowing, geographies of ignorance: Jumping scale in Southeast Asia. Environment and Planning D: Society and Space, 20(6), 647-668.

Sellato, B. (2002). History and myth among Borneo people. Innermost Borneo Studies in Dayak Cultures (pp. 137-162). Singapore University Press.

Sellato, B. (2016). The Ngorek of the central highlands and 'megalithic' activity in Borneo. In C. Jeunesse, P. Le Roux and B. Boulestin (Eds.), Mégalithismes vivants et passés: Approches croisées. Living and Past Megalithisms: interwoven approaches (pp. 117-149). Archaeopress, Archaeology.

Stenzel, K. (2005). Multilingualism: Northwest Amazonia Revisited. Proceedings of the Second Annual Congress CILLA Congreso de Idiomas Indígenas de Latinoamérica II (CILLA). [http://www.ailla.utexas.org/site/cilla2_toc_sp.html]

Strolich, N. (2018, April). The Race to Save the World's Disappearing Languages. National Geographic. $\quad$ https://www.nationalgeographic.com/news/2018/04/saving-dying-disappearinglanguages-wikitongues-culture/

Thambiah, S. (2020). Revisiting the question of rank and egalitarianism in Borneo: the ways in which hierarchy is expressed, maintained and lost amongst the Bhuket of Sarawak. In K.G. Ooi (Ed.). Borneo and Sulawesi, indigenous peoples, empire and area studies (pp. 158-175). Routledge.

Tsing, A.L. (1994). In the realm of the diamond queen. Princeton University Press. 
Walchren, E.W.F. van. (1907). Eene reis naar de Bovenstreken van Boeloengan (middenBorneo). Tijdschrift van het Koninklijk Nederlandsch Aardrijkskundig Genootschap, 24, 755-844.

Zawawi, I. (Ed.) (2008). Representation, identity and multiculturalism in Sarawak. Dayak Cultural Foundation/Persatuan Sains Sosial Malaysia. 